\title{
A ZOOMORFIZAÇÃO E A DESUMANIZAÇÃO NO ROMANCE O REMORSO DE BALTAZAR SERAPIÃO DE VALTER HUGO MÃE
}

\author{
Murilo de Assis Macedo Gomes'
}

\begin{abstract}
RESUMO: O objetivo desse artigo é discutir o processo de zoormofização e desumanização das personagens na obra $O$ remorso de baltazar serapião (2010), do escritor português Valter Hugo Mãe. Esse processo está em consonância com a organização social tratada no romance, no qual prevalece uma estrutura hierárquica rígida e arcaica, típica da Idade Média. Nesse tipo de sociedade, o papel de cada homem era delimitado de acordo com suas origens sociais e econômicas. Desse modo, percebe-se na obra um fatalismo do destino associado à vida das personagens. A elas é atribuída uma certa condição animalesca que as metamorfoseia em seres híbridos, cujas características encontradas em outros animais as constituiriam. Nesse processo, todas, com exceção de El-rei e da rainha, são zoomorfizadas e algumas, tais como as personagens femininas, são, sobretudo, desumanizadas. Em contraste a isso, a vaca, Sarga, da família de Baltazar é paulatinamente humanizada no decorrer da narrativa.
\end{abstract}

PALAVRAS-CHAVES: Valter Hugo Mãe; Literatura Portuguesa; desumanização; zoomorfização.

\section{THE ZOOMORPHISATION AND THE DE-HUMANIZATION IN THE NOVEL O REMORSO DE BALTAZAR SERAPIÃO BY VALTER HUGO MÃE}

\begin{abstract}
The objective of this article is to discuss the process of characters' zoomorphisation and de-humanization in the book $O$ remorso de baltazar serapião (2010), by the Portuguese writer Valter Hugo Mãe. This process corresponds to the social organization carried out in the novel, in which a strict and archaic hierarchical institution, typical of the Middle Ages, rules. In this type of society, each man's role is limited according to his social and economical reasons. Therefore, in the book there is a fatalistic destiny associated with characters' lives. To them, it is attributed some sort of animal condition that metamorphoses them into hybrid beings, whose characteristics found in other animals constitute them. In this process, every character, except El-rei (the King) and the queen, is zoomorphised and some, such as the female characters, are, above all, de-humanized. In contrast, the cow, Sarga, which belongs to Baltazar's family, is humanized along the text.

KEYWORDS: Valter Hugo Mãe; Portuguese Literature; de-humanization; zoomorphisation.

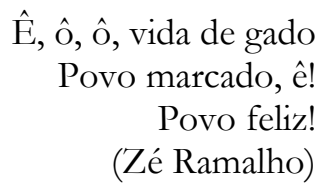

A obra O remorso de baltazar serapião (2010), publicada pelo escritor angolano Valter Hugo Mãe, cujo enredo pode remeter a algum lugar de Portugal na Idade Média, trata de

\footnotetext{
${ }^{1}$ Mestre (2010) e doutor (2016) em Letras, Literatura Portuguesa, pela Universidade de São Paulo. Estuda a obra do romancista José Saramago sob a óptica das teorias do espaço e do discurso. Atualmente é professor na Universidade Paulista (UNIP).
} 
uma determinada organização social hierarquizada onde os indivíduos têm poucas possibilidades de mudança de seu destino.

O espaço principal da obra é uma propriedade rural cujo dono é Dom Afonso, homem de posses, que parece dominar, para além das terras, a vida e a vontade das pessoas, a começar pelo domínio que exerce sob a família de Baltazar, cuja alcunha, Sargas, substitui o verdadeiro sobrenome da família, Serapião. Essa mudança, associada ao nome do animal de estimação da família de Baltazar, a vaca Sarga, já indica logo no início da narrativa a aliança e a consecutiva aproximação do universo humano ao universo animal como se organiza no romance. A vaca Sarga é posta logo nas primeiras linhas da narrativa numa condição superior até à das personagens femininas que aparecerão posteriormente, tais como a irmã de Baltazar (Brunilde), sua mãe e sua futura esposa Emersinda. As vozes das mulheres estão, sob essa ótica, abaixo do mugido da Sarga:

a voz das mulheres estava sob a terra, vinha de caldeiras fundas onde só diabo e gente a arder tinham destino. a voz das mulheres, perigosa e burra, estava abaixo de mugido e atitude da nossa vaca, a sarga, como lhe chamávamos. (MÃE, 2010, p. 11)

Percebe-se, na passagem, que as mulheres são seres diabólicos e que suas vozes não são ouvidas dentro daquela sociedade. De acordo com Deleuze,

com efeito, as relações dos animais entre si não são, por um lado, apenas objeto de ciência, mas também objeto de sonho, objeto de simbolismo, objeto de arte ou de poesia, objeto de prática e de utilização prática. Por outro lado, as relações dos animais entre si são tomadas em relações do homem com o animal, do homem com a mulher, do homem com a criança, do homem com os elementos, do homem com o universo físico e microfísico. (DELEUZE, 1997, p. 14)

É válido ressaltar que, para Deleuze, o animal, assim como a mulher e a criança, não são considerados como sujeitos constituídos, pois estão em constante devir em relação ao homem branco, heterossexual, europeu, considerado o padrão em relação aos outros seres, por ele subjugado. Na obra de Mãe, Dom Afonso, proprietário das terras e dos seres que ali vivem, é homem, é rei e tem poder, quer dizer, estabelece o padrão a ser seguido pelas outras personagens. Baltazar e sua família são rebaixados socialmente por serem propriedade de Dom Afonso, que os explora assim como explora a terra e os animais que 
nela estão. Os Sargas são zoormorfizados e desumanizados ao menos na perspectiva do narrador, que diz:

mal tolerados por quantos disputavam habitação naqueles ermos, batíamos os cascos em grandes trabalhos e estávamos preparados, sem saber, para desgraças absolutas ao tamanho de bichos desumanos. tamanho de gado, aparentados de nossa vaca, reunidos em família como pecadores de uma mesma praga, maleita nossa, nós, reunidos em família, haveríamos de nos destituir lentamente de toda a pouca normalidade. (MÃE, 2010, p. 11, grifo nosso)

É importante observar as analogias feitas pelo narrador em sua escolha vocabular em relação às condições de Baltazar e, por consequência, de sua família naquele lugar. Os Sargas tinham esse nome porque se pareciam com a Sarga, uma vez que também "batiam os cascos", viviam como "bichos desumanos" e só podiam ser da vaca "aparentados". Nesse sentido, há aqui uma relação de aliança entre o mundo humano e o mundo animal. O processo de zoormofização e de desumanização não é, nesse caso, estanque e definitivo, mas ele percorre toda a narrativa, fazendo com que Baltazar e sua família se zoomorfizem e que a vaca Sarga se humanize progressivamente. No sentido dado por Deleuze (1997), há na obra um devir vaca para Baltazar e sua família; bem como um devir homem para Sarga, a vaca, e também para Baltazar e sua família que estão em um não-lugar (pois não são homens como Dom Afonso, como também não são propriamente gado como são vistos pelo dono e pelo restante da sociedade que os cerca). Logo, vivem uma crise de identidade, pois não são vistos completamente como humanos, mas também não são identificados totalmente como animais. Isso se evidencia em várias partes da narrativa, como na conversa de um curandeiro com Afonso (pai de Baltazar) e Aldegundes, na qual o homem põe em dúvida a maternidade dos meninos, sugerindo que eles são filhos da vaca:

o curandeiro farto de garantir que a minha mãe estava seca como uma pedra, impossível vir dali alguma criança, bicho ou coisa. não pode vir nada, gritava o senhor santiago, nada, como arranjou estes filhos contenos o senhor sarga, porque da sua mulher nem adianta pensar nisso, deus até lhe corta a língua. e como se dizia, que éramos filhos da sarga, sem grandes rodeios, éramos como filhos da sarga. (MÃE, 2010, p. 40)

Baltazar e seu irmão, Aldegundes, eram como bestas, minotauros, criaturas mitológicas cujo corpo se constitui de uma parte humana e outra animal, como se 
apresenta nos mitos associados ao labirinto de Dédalo, percorrido por Teseu a mando do rei de Creta a fim de dar fim ao sacrifício sanguinário dos rapazes e moças cretenses que eram servidos em ritual como exigência da besta. Em certa medida, o destino de Baltazar Serapião e dos seus acaba por se aproximar do destino do minotauro mítico, pois eles também são encerrados no centro de um labirinto, sob o domínio de um rei, monarca, senhor, representado pela figura de Dom Afonso, que os sacrifica diariamente na lida do trabalho bruto do campo, reduzindo a possibilidade de escolha daqueles seres ao enclausuramento de uma vida limitada somente a condições de subsistência. Vale ressaltar que essa metáfora é parcial, uma vez que, diferentemente do Minotauro mítico que fora preso para proteger a população de Creta de sua violência, Baltazar e sua família são explorados e não oferecem nenhum risco à comunidade onde vivem.

A ironia do destino de Baltazar Serapião ultrapassa sua própria condição de ser bestificado, e sua suposta origem materna duvidosa, que está, ao menos no imaginário daquela comunidade, associado à vaca, Sarga, encontrando-se até mesmo em seu apelido de família (os Sargas). O sobrenome Serapião, em um processo de aglutinação do verbo "será" com o substantivo "pião", pode remeter ao brinquedo que gira em torno de si mesmo com poucas chances de sair do lugar onde foi lançado pelo jogador. Nessa perspectiva, assim como o minotauro mítico, Baltazar não deverá encontrar saída, a não ser a do flagelo que o atinge até o fim dessa história.

A vida de Aldegundes, irmão de Serapião, cuja possibilidade de saída do vilarejo se dá a partir da descoberta de seu talento como artista plástico e do fim frustrado de uma viagem, demonstra ao leitor a impossibilidade de libertação que cerca a vida daquelas personagens. Aldegundes torna-se um talentoso pintor de uma hora para outra. De maneira misteriosa, o rapaz passou a fazer pinturas que chamavam a atenção de todos, inclusive de El-rei e, por esse motivo, foi por ele chamado para fazer as pinturas das igrejas da realeza:

e o nosso aldegundes arranjaria coisa que nos mudaria todo o tempo futuro por mais ainda que desconhecêssemos o que tanto seria. el-rei daria mudança, de nossa terra se alta e valiosa, a chegar às nuvens e a baixar-se terra dentro, com catacumbas para celas de cativos ou esconderijos de tesouros impossíveis de arrebatar. deus nosso, que milagre saía de boca de el-rei, comentado com a brunilde em braço enrolado com o nosso aldegundes, que pintado tão perfeito estavam os rostos de dom afonso e dona catarina, estaria o aldegundes em obrigação para com sua majestade a pintar-lhe figura em tábuas maiores para orgulho de reino inteiro. partirás em direção ao palácio, chegarás para 
ficar tempos que te ocupem, e serás recompensado por tão grande talento. foi como próprio rei falou, diretamente falado com ele. (MÃE, 2010, p, 105)

Essa viagem, em atendimento ao chamado de El-rei, será malfadada, como se saberá adiante no desenvolvimento do enredo. Tudo havia se passado de modo inesperado devido ao encontro de Baltazar e Aldegundes no caminho com uma mulher queimada que os havia amaldiçoado e, por essa razão, eles não haviam conseguido êxito na empreitada. Devido a tal maldição, acabaram sendo expulsos por El-rei: "partimos de imediato, el-rei nos expulsou” (MÃE, 2010, p. 141). Nesse momento, é importante notar que as personagens do romance de Mãe têm uma certa vocação para o pacto com o diabo. Tratase de personagens em sua maioria pobres e de vida errante, cujo infortúnio parece persegui-las impiedosamente. O reino simbólico da história que se apresenta ao leitor é o da tragédia de uma vida assolada pela miséria em todos os sentidos possíveis do ser. A miséria ronda Baltazar Serapião e aqueles que o cercam, demonstrando suas múltiplas facetas, a miserabilidade das relações entre homens e mulheres em uma sociedade machista, a miserabilidade das relações entre patrões e empregados, a miserabilidade das relações humanas, enfim. As personagens se apresentam de um certo modo possuídas pelo demônio e, de certa maneira, iludidas, são incapazes de enxergar outras possibilidades para a vida. Há, em $O$ remorso de baltaz̧ar serapião, um destino trágico que retira das personagens toda e qualquer possibilidade de mudança para uma condição de vida superior e melhor que aquela na qual elas se encontram. Essa associação ao bestial, no sentido mais instintivo e vil do termo, leva as personagens a um grau de agressão física (principalmente) mas nãoverbal (de tal modo naturalizado) que chega a causar espanto ao leitor; porém, ao mesmo tempo não o incomoda, uma vez que o narrador o faz de modo tão espontâneo que ao leitor tudo passa a parecer normal e possível dentro do enredo. A tragédia eminente dos Sargas se propaga até mesmo na figura de Aldegundes, o artista talentoso, mas desprovido de sorte, e chega ao seu limite no tratamento animalesco e desumano concedido às mulheres de maneira geral, mais especificamente às Sargas, como se mostra ao longo de toda a narrativa, a começar por Brunilde, irmã de Baltazar, escolhida desde a tenra idade para saciar os desejos sexuais de Dom Afonso. Além disso, as mulheres, de maneira geral, são vistas pelo narrador e pelas personagens masculinas como animais que serviam apenas para saciar o desejo sexual dos homens e/ou para procriar. Esse é o destino de Brunilde, de 
Emersinda, da mãe de Baltazar, de dona Catarina, esposa de Dom Afonso, e de Teresa Diaba. Isso se pode evidenciar em vários trechos da obra:

\begin{abstract}
a teresa diaba era quem vinha muito por mim. parecia uma cadela no cio, farejando, aninhada pelos cantos das árvores e dos muros, à espera de ser surpreendida por macho que a tivesse. era toda carne viva, como ferida onde se tocasse e fizesse gemer. abria-se como lençóis estendidos e recebia um homem com valentia sem queixa nem esmorecimento. era como gostava, total de fúria e vontade, sem parar, a ganir de prazer. não queria mais nada senão esses ocasionais momentos, estropiada da cabeça, torta dos braços, feia, ela só servia de mamas, pernas e buracos, calada convicta, era como um animal que fizesse lembrar uma mulher, servia assim como melhoria de uma vez que tivéssemos de fazer com a mão. (MÃE, 2010, p. 27-28, grifo nosso)
\end{abstract}

Nas primeiras palavras que caracterizam a personagem Teresa Diaba pelo narrador percebe-se um processo de desumanização e desassujeitamento da mulher em prol da zoormofização ou da animalização de seu ser enquanto indivíduo que age de maneira totalmente instintiva e irracional, servindo tão somente para a copulação com um macho da espécie. Teresa Diaba "parecia uma cadela no cio" e "era como um animal que fizesse lembrar uma mulher", pois "só servia de mamas, pernas e buracos". Ocorre que não se trata tão-somente de uma inversão ou transformação da mulher em um animal, pois as personagens masculinas também se portam em vários momentos como bichos. Existe, no romance, uma zona intermediária do humano e do animalesco, que Valter Hugo Mãe explora com maestria. As personagens ora se aproximam de uma condição mais instintiva e são zoomorfizadas pelo narrador, ora também são humanizadas por suas atitudes contraditórias. Nesse ponto, o romance está num espaço intermediário da aliança entre o homem e a natureza, demonstrando os aspectos mais grotescos e sensíveis da sua condição.

\title{
Conforme Deleuze,
}

as participações, as núpcias anti-natureza, são a verdadeira Natureza que atravessa os reinos. A propagação por epidemia, por contágio, não tem nada a ver com a filiação por hereditariedade, mesmo que os dois temas se misturem e precisem um do outro. (...) A diferença é que o contágio, a epidemia coloca em jogo termos inteiramente heterogêneos: por exemplo, um homem, um animal e uma bactéria, um vírus, uma molécula, um microorganismo. (...) Combinações que não genéticas nem estruturais, inter-reinos, participações com a natureza, mas a Natureza só procede assim, contra si mesma. (...) $\mathrm{O}$ Universo não funciona por filiação. Nós só dizemos, portanto, que os animais são matilhas, e que as 
matilhas se formam, se desenvolvem e se transformam por contágio (DELEUZE, 1997, p. 22-23).

Sob essa perspectiva, a vida humana e a vida animal não podem ser vistas como totalmente diversas, numa relação de superioridade, geralmente atribuída ao homem, e de inferioridade, indicada ao animal. Sob o viés deleuziano, os animais, e aí também entram os homens, não devem ser classificados por filiação e categorizados em espécies, uma vez que tais classificações acabam por fugir do dinamismo da vida que, em contextos diversos, promove a aliança entre os seres. Portanto, partindo desse pensamento, pode-se dizer que há algo em comum entre a molécula, a bactéria, o vírus, os animais e os homens que contraria a ideia de segmentação e divisão em categorias ou espécies. A ideia da matilha, do bando, da multiplicidade tem como sentido a integralidade entre os seres vivos, ou seja, aquilo que há de comum entre os mais distintos seres vivos, a vida, a luta pela sobrevivência, a necessidade de se alimentar, o desejo sexual etc.

Nesse sentido, na obra de Valter Hugo Mãe, percebe-se que a noção de desumanização e zoomorfização das personagens funciona como o contágio da matilha definido por Deleuze, já que atravessa todas as personagens, independentemente de suas condições econômicas e sociais dentro daquela sociedade. Isso se ratifica pelo comportamento das personagens das mais distintas classes sociais: de Dom Afonso e Dona Catarina, passando por Baltazar e a família, até El-rei. De maneira geral, as personagens em O remorso de baltazar serapião (2010) agem como uma matilha ou um bando, uma vez que se contagiam por comportamentos semelhantes e acabam sendo vítimas e, ao mesmo tempo, algozes do contexto no qual estão enredados. A relação de contágio desse bando se dá de maneira diabólica. As personagens de maneira geral, parecem estar possuídas por desejos e vontades diversas. Na continuação da descrição de Teresa Diaba isso se evidencia, o que seria óbvio se se pensasse no apelido dado à personagem, que já carrega o diabo no nome. Entretanto, a presença manifesta do diabo parece perfazer o destino da vida de todas aquelas personagens. Sobre Teresa Diaba, o narrador diz:

a teresa diaba era assim chamada porque fumegava das ventas quando enervada, não era mentira nem conversa das pessoas, era mesmo assim, inalava muito, bufava, encarnava-se de fúria com facilidade, assim víamos a encher a cara de sangue como vinho dentro de uma tigela, e depois as narinas abriam-se para fumegarem como canais de vapor para alívio das caldeiras do seu coração, eu dizia-lhe que parasse de bater os 
cascos no chão, que fizesse pouco barulho ou viriam descobrir-nos ali nas pedras, enganchados um no outro. (MÃE, 2010, p. 28, grifo nosso)

Vê-se que a descrição é carregada de um simbolismo infernal. A personagem tem aspecto físico totalmente avermelhado (da cor do diabo), como se pode verificar no imaginário popular advindo da Idade Média, tempo próprio da narrativa. O autor parece recorrer às imagens de Dante, de seres bisonhos que habitavam os círculos do inferno da Divina Comédia. Teresa Diaba, na descrição, pode ser vista como o próprio diabo ou como uma força feminina capaz de devorar os homens através da luxúria, visão em voga na Igreja da Idade Medieval. Além disso, conforme Baltazar, o narrador-personagem, Teresa, assim como um dos Sargas, também bate "os cascos no chão", reafirmando a imagem do minotauro tratada anteriormente. Desse modo, tal imagem corresponde na obra não apenas à família de Baltazar, os Sargas, parentes da vaca, mas, sobretudo, a outras personagens, como é o caso da Teresa Diaba. Percebe-se, na continuidade da descrição da personagem, a fusão entre o homem e o animal, tanto em seus aspectos físicos como em seus aspectos comportamentais, já que Teresa "parecia uma cadela no cio, farejando, aninhada pelos cantos das árvores e dos muros, à espera de ser surpreendida por macho", ou ainda uma besta ou uma vaca que "fumegava das ventas" e "bufava, encarnava-se de fúria com facilidade", cuja única finalidade de sua existência era a de saciar os desejos de Baltazar e de outros homens da comunidade, já que "só servia de mamas, pernas e buracos". A imagem do minotauro é recorrente nessa obra de Mãe. A besta aparece aí como síntese do mundo racional e sentimental, próprio do homem, mas também como símbolo do universo irracional e instintivo desse mesmo homem e de tantos outros animais. Dessa maneira, o autor recorre à imagem de animais para demonstrar o quão semelhante os homens são a eles e não tão diferentes como imaginam que sejam. É por isso que parece ao leitor que os homens retratados na narrativa se bestializam, ao passo que os animais se humanizam. Essa impressão serve como argumento da obra para mostrar o grau de elo e de semelhança entre universos aparentemente distintos. Contudo, é importante ressaltar o grau de violência com que as mulheres são tratadas nessa sociedade, dentro desse processo contínuo de desumanização.

Além da Teresa Diaba, outras são as personagens que, se não são zoomorfizadas completamente, são desumanizadas na narrativa. Dentre elas, destacam-se Brunilde e a mãe 
de Baltazar Serapião. Brunilde, como já foi adiantado, tem como destino satisfazer o proprietário daquelas terras e daqueles corpos, como diz o narrador a respeito dela:

\begin{abstract}
quando os senhores a levaram, foi dom afonso quem disse que era moça de valentia, haveriam de lhe dar aconchego nos afazeres, e só quando fortalecesse o tronco, e as pernas segurassem melhor, teria afazeres de grande responsabilidade. era o que ela confirmava quando vinha aos legumes e ao leite. que era assim que fazia, deixada pela casa, ao pó e carregando pequenos objetos, e falso seria porque o tronco não se fortalecesse, eu percebera muito antes de que mo disse, era para que se conservasse boa de aparências, com a pele clara e as mãos ágeis, assim a queria o senhor para as sevícias que lhe davam a ele, a esfregar-se e a meter-se nela pelos cantos da casa, a tentar retribuir-se de tudo o que a dona catarina, velha de carnes, descaída e dada às maleitas, já não lhe oferecia. (MÃE, 2010, p. 20)
\end{abstract}

A mulher, nessa obra de Mãe, é representada, em muitos momentos, como simples objeto sexual, que tem como um de seus papéis saciar o desejo dos homens e, em alguns casos, procriar e cuidar dos filhos, do marido e da casa, sendo, muitas vezes, vítima da violência e do abuso dos homens, como o faz Baltazar com Emersinda, a exemplo do que viu o seu pai, Afonso, fazer com a mãe ao longo da vida. As mulheres parecem não ter voz para "não encher os ouvidos dos homens com ignorâncias perigosas. uma mulher é ser de pouca fala, parideira e calada, explicava o meu pai, ajeitada nos atributos, procriadora, cuidadosa com as crianças e calada para não estragar os filhos com seus erros." (MÃE, 2010, p. 17). Entretanto, esse não é o destino de todas as mulheres do vilarejo. Algumas são escolhidas ou deixam de sê-lo, dependendo do ponto de vista, a fim de servirem para outras finalidades que não aquelas do lar. Essas são as prostitutas e/ou mendigas com grande apetite sexual, como Teresa Diaba, ou ainda as amantes, como é o caso de Brunilde, irmã de Baltazar Serapião, o narrador. Como se evidencia no trecho acima, Brunilde foi escolhida por Dom Afonso para ser sua amante, para ocupar o lugar de sua esposa Dona Catarina, que já é uma mulher idosa e adoentada. Percebe-se que a mulher, nessa sociedade, é como um objeto cujo valor principal se encontra no uso que os homens fazem de seus corpos. Uma vez velhas e adoecidas, elas são abandonadas e trocadas por outra mais jovem. Desse modo, à Brunilde Dom Afonso oferece regalias e favores para poupá-la do serviço bruto do campo, deixando-a fazer tão somente os trabalhos mais leves, a fim de preservá-la para seu deleite, nem que para isso tenha que fazê-la sofrer. Dom Afonso representa o padrão machista desse tipo de sociedade, na qual as principais decisões acerca 
até mesmo das vontades de outros seres são tomadas pelos homens a revelia do respeito que se deve à diferença e à multiplicidade de pensamentos dos mais distintos sujeitos de gêneros diversos. Nesse caso, a questão não é quantitativa, mas qualitativa.

A obra trata das mais variadas formas de ser no mundo, ainda que algumas estejam fora do padrão desejado. Baltazar foge ao padrão em relação a Dom Afonso por ser pobre e por "devir" animal, uma vez que se assemelha à vaca. O padrão máximo é El-rei e a rainha, nos quais Dom Afonso e Dona Catarina se espelham, tendo-os como referência. As outras personagens fogem ao padrão por não serem homens ricos, mas ao contrário, são pobres, trabalhadores do campo, prostitutas e feiticeiras. Desse modo, essas personagens estão à mercê das decisões tomadas por outras, que aparentemente têm características enobrecedoras, como Dom Afonso e Dona Catarina, senhores feudais.

Conforme Deleuze,

a noção de minoria, com suas remissões musicais, literárias, linguísticas, mas também jurídicas, políticas, é bastante complexa. Minoria e maioria não se opõem apenas de uma maneira quantitativa. Maioria implica uma constante, de expressão ou de conteúdo, como um metro padrão em relação ao qual ela é avaliada. Suponhamos que a constante ou metro seja homem-branco-masculino-adulto-habitante das cidades-falante de uma língua padrão-europeu-heterossexual qualquer (o Ulisses de Joyce ou de Ezra Pound). É evidente que "o homem" tem a maioria, mesmo se é menos numeroso que os mosquitos, as crianças, as mulheres, os negros, os camponeses, os homossexuais... etc. É porque ele aparece duas vezes, uma vez na constante, uma vez na variável de onde se extrai a constante. A maioria supõe um estado de poder e de dominação, e não o contrário. (...) Uma outra determinação diferente da constante seria então considerada como minoritária, por natureza e qualquer que seja seu número, isto é, como um subsistema ou como fora do sistema. (DELEUZE, 1995, p. 55)

Sob essa perspectiva, todas as personagens, com exceção de Dom Afonso e El-rei, escapam, em certa medida, do padrão majoritário de poder que essas personagens exercem sobre aquelas. Ainda que estejam maioria numérica, as mulheres e os camponeses passam a ser minoria, uma vez que não exercem o poder de decisão e de escolha sobre suas próprias vidas, permanecendo sob o jugo dos poderosos. Isso não quer dizer que essas personagens que são excluídas do sistema e fogem do padrão não exerçam poder algum, mas, à medida que vão se afastando do padrão, o seu poder é cada vez mais reduzido. 
Desse modo, há, no romance, uma hierarquia do poder, em que El-rei está no topo da pirâmide e as mulheres camponesas e pobres, na base. Sendo assim, o poder é distribuído, de acordo com o lugar que cada um desses sujeitos exerce naquela sociedade. $\mathrm{Na}$ medida em que se afastam do padrão majoritário de poder, as personagens são vistas pelo narrador e se veem como seres híbridos, pertencentes a um reino simbiótico que mescla o humano ao animal e passam a agir de modo instintivo e por vezes até irracional, fugindo à lógica do poder dominante. As minorias na obra de Valter Hugo Mãe são zoomorfizadas e bestializadas, mas isso não quer dizer que elas se aproximem da condição animal para demonstrarem apenas algum aspecto negativo de sua personalidade que as distancie do homem enquanto ser racional, mas tal condição acaba por aproximá-las dos animais também na falta de autonomia que elas podem ter diante da vida, já que acabam se submetendo às vontades de um dono. Além disso, nessas personagens é possível notar um certo fatalismo diante da vida, cuja impossibilidade de mudança de destino é certa, própria do gado que vai na fila, sabendo que será o próximo a ser abatido, mas que não há nada que se possa fazer.

Se "a maioria supõe um estado de poder e de dominação", como afirma Deleuze, em o remorso de baltazar serapião, essa maioria refere-se de fato aos homens, que acabam sendo opressores das mulheres. Ainda que tais homens não atinjam majoritariamente o padrão de El-rei ou de Dom Afonso (por estarem, também, em relação a eles fora do sistema se comparados ao padrão), são pobres camponeses, que também são zoomorfizados, como demonstra o relato do narrador. Sendo assim, os homens, de modo geral, também fogem ao padrão por não serem ricos e poderosos e não terem autonomia para decidirem sobre suas próprias vidas. Entretanto, as mulheres fogem ao padrão duplamente: primeiro por serem, como a maior parte dos homens, pobres e rudes, e depois por serem simplesmente mulheres. Isso se ratifica no grau de animalização do qual quase todos são vitimados: "aninhados todos um tempo depois, meu pai, minha mãe, o aldegundes, eu e a emersinda, metidos para o chão amuados como tristes estafermos, a juntarmos as mão aos pés, sentido-lhes a rudeza como cascos, feitos gado a que sempre cheiráramos.” (MÃE, 2010, p. 49).

A tradição patriarcal da mutilação dos corpos femininos persiste através da cultura machista de uma sociedade, que passa de geração a geração, com modos e costumes arcaicos que se perpetuam ao longo da história, como ocorre com a mãe de Baltazar e 
principalmente com Emersinda, vítima dos abusos de Dom Afonso (que passa a obrigá-la a manter relações sexuais com ele) e também dos ciúmes do marido (cônscio da situação, mas temeroso de atentar contra o patrão e, com isso, perder o emprego, o alimento e o lar de toda sua família).

Sobre sua mãe, Baltazar se referia a ela da seguinte maneira: "a minha mãe não discernia senão sobre lidas da casa. estropiada do pé, pouco capaz de ver, ficara inutilizada para as coisas dos senhores” (MÃE, 2010, p. 17). Mais à frente, quando está próximo do momento da morte dela, diz:

\begin{abstract}
esmagada nas mãos e pés do meu pai, rogando praga para que a sua alma se vendesse ao inferno, e por trela seguiria minha mãe, tremida e mijada de muito medo, assim oferecida por seu senhor ao corno do inferno, não queria imaginar, minha mãe tão velha, cega e estropiada e feia, metida com quem lhe entrasse dentro, que prazer mórbido seria o das coisas no sexo com velhas mulheres casadas, já prontas a entregar tudo à terra para poupança do nojo comum. mas, se tardaria muito, haveria de ser muito vil a sua alma, assim rendida às carnes de outro homem, que não o meu pai, se meu pai a matasse de dores infinitas e raiva, mataria de razão para que purgasse sua alma a pedido do amor, talvez deus a salvasse após longo suplício, para depois a devolver à paz e para que meu pai a pudesse reencontrar nas águas do paraíso, apagada de todo o fogo que a consumira, eternamente cicatrizando as feridas, retomando com anos a beleza que tivera. no paraíso até as coisas tortas se endireitariam, postas no lugar de origem para serem benignas, e regressados à beleza inicial seriam apaixonadas para sempre com essa força dos principiantes no amor. (MÃE, 2010, p. 55)
\end{abstract}

Observa-se, no trecho, que a vida da mãe de Baltazar é sofrida e triste. Ela também havia sido vítima da violência do marido, pois foi por ele "esmagada", e tais atos encontravam o apoio do filho, que via numa suposta traição da mãe o motivo mais que justo para sua morte, já que, como ele mesmo diz, "se meu pai a matasse de dores infinitas e raiva, mataria de razão”. Ao pensar desse modo, Baltazar acaba por reproduzir os atos de seu pai em relação à mulher, perpetuando assim em seu casamento o mesmo desastre da vida conjugal de seus pais em seu próprio matrimônio com Emersinda.

O remorso de baltazar serapião (2010) é um romance cujo destino das personagens é a tragédia humana que conjuga o espaço da terra ao espaço do inferno. Trata-se de uma obra que traz o signo da terra, do barro, do campo, arado e cuidado pelo camponês, que cuida das verduras, dos legumes e dos bichos no pasto, mas que ao mesmo tempo sobrevive às condições próprias do inferno, abrasado por calores diversos, advindos da terra cuja seca 
assola, mas também e sobretudo advindos das fortes e intensas relações passionais que levam os homens a praticarem atos sórdidos, ainda que sejam encobertos por uma aura de ingenuidade e ignorância que fazem com que o leitor, em muitos momentos, se solidarize com esses homens, dado o elevado grau de humanidade que o autor atinge na confecção de suas personagens. O fogo aparece na obra como elemento, como símbolo dos mais variados significados: às vezes está associado ao poder de sedução e de traição do diabo, na figura da personagem Teresa Diaba (cujas relações promíscuas com Baltazar, Aldegundes e tantos outros homens fazem com que ela seja associada à fêmea demoníaca). Já na passagem acima citada, pode-se observar que o fogo designa a purificação e a renovação da vida, pois "talvez deus a salvasse após longo suplício, para depois a devolver à paz e para que meu pai a pudesse reencontrar nas águas do paraíso", fazendo com que os pais de Baltazar pudessem voltar a uma condição anterior, a uma espécie de éden, paraíso primordial, onde se pode encontrar a paz tão desejada, já que "no paraíso até as coisas tortas se endireitariam, postas no lugar de origem para serem benignas, e regressados à beleza inicial seriam apaixonadas para sempre com essa força dos principiantes no amor.”. O fogo, nesse sentido, juntamente com as "águas do paraíso", é capaz de renovar a vida. Entretanto, é importante notar que o pecado aparece no romance simbolicamente, visto pelo narrador, como o pecado original, associado à mulher. Sendo assim, os homens podem trair e cometer atos vis, mas não devem ser punidos por isso, afinal tais atos são fruto da sedução da mulher e são elas que devem ser castigadas. No trecho acima, o narrador perdoa até mesmo um suposto assassinato da mãe pelo pai, considerando que a loucura proveniente de tal ato só pode ter como origem a mulher, como se pode evidenciar também na seguinte passagem:

meti-me em casa sem ânimo nem brio, trabalhar de cornos à mostra não era coisa de aguentar, tentava justificar-me à minha mãe, estropiada de tudo na cama onde meu pai a pusera, só gemia mais ainda por ter de constatar a condenação do sexo fraco, as mulheres são frutos podres, como maças podres, raios hão de partir eternamente a eva por ter sido mal lavada nas intenções. e, quando a emersinda puser aqui o pé, o primeiro que lhe acontece é ficar com ele torcido duas vezes o da mãe, para não esquecer nunca mais, sem pio, que deve vir de artimanhas para me iludir, será sem aviso e sem tempo algum que se terá torta para o curandeiro acudir. (MÃE, 2010, p. 52) 
As mulheres, na perspectiva do narrador, pertencem ao "sexo fraco" e são "podres". A elas está associada toda a origem do mal desde o éden de Eva. Dessa forma, são vistas como seres amaldiçoados devido à desobediência primordial no paraíso, e por isso, em certa medida, são seres inferiores aos próprios animais no enredo da trama de Mãe. Se comparado ao tratamento despendido a elas e à vaca Sarga ao longo da narrativa, observa-se que os homens daquela família têm apreço, amor e carinho pela vaca, o que nem sempre demonstram por suas mulheres. Vê-se que o destino de Emersinda é praticamente um duplo da condição da mãe do narrador: ela ficará com os pés torcidos e cega (assim como sua sogra) devido às supostas traições que pode ter cometido contra seus maridos, traições essas que são fruto do abuso de poder de homens como Dom Afonso, e das quais essas mulheres também eram vítimas. A mulher aparece na obra de Mãe como um ser híbrido, em parte mulher, mas também diaba, bruxa, promíscua, amaldiçoada e traidora. Nesse sentido, está em uma condição minoritária nas relações de poder, o que a coloca em um patamar abaixo dos próprios animais, como a vaca Sarga, que tinha a atenção, o carinho e o amor de seus donos, o que às mulheres não era dispensado. Isso não será diferente com Emersinda, como admite o narrador:

eu rondava-a e imaginava-lhe o pé torto a entortar o outro por simpatia, a fazê-la como pata de andar aberto para nadar nas águas de um lago. havia de lho entortar e arrancar se lhe descobrisse uma prova. puta, calada de segredos fundos, satisfeita com ser refeição de um velho tão feio. (...) pois que morresse. se eu não amasse, se pudesse lavar o nome do meu pai sem saudade, de vez por todas a fazia desaparecer víbora para dentro da terra. (MÃE, 2010, p. 64, grifo nosso)

É possível notar, nas palavras de Baltazar, o narrador, uma mistura de emoções e sensações, já que ele considera sua esposa uma "puta" de Dom Afonso e uma "víbora" por se silenciar e fazer parte da traição. Ao mesmo tempo, Baltazar diz que a ama, e por isso não quer matá-la. Essa desconfiança em relação a um possível caso amoroso que sua mulher pode ter com o proprietário da fazenda, Dom Afonso, faz com que ele queira vingar o seu ódio em relação ao patrão na mulher, que era o ser mais frágil dessa relação. Baltazar tinha como objetivo se vingar de Emersinda, entortando-lhe mais um pé, assim como seu pai, Afonso, havia feito à sua mãe, também motivado pelos ciúmes dos abusos cometidos por Dom Afonso no passado, como se evidencia na fala entre pai e filho, narrada por Baltazar: 


\begin{abstract}
ficou-lhe o pé para dentro, ao invés do de minha mãe que lhe tinha ficado para fora, ficou-lhe para dentro e até um pouco para trás, e doíalhe muito, e o meu pai viu-a e disse, eis o teu corno men filho, se não tivesses feito o povo esqueceria, assim vais ter os cornos à mostra a vida toda. não percebera, $e$ falava a experiência, e se calhar dizia-me que devia tê-la matado para a enterrar como cornadura inteira, longe das vistas da gente. se não morrera, e como a amava eu, haveria de ser uma fraqueza minha para sempre, como no íntimo assim a aceitava, à vista de todos. (MÃE, 2010, p. 54 , grifo nosso)
\end{abstract}

A revelação de Afonso, pai de Baltazar, mostra o real motivo da mutilação do corpo de sua mãe, pois, em algum momento, ela também deve ter sido abusada sexualmente por Dom Afonso e, assim como Baltazar, o pai não podia medir forças com o proprietário daquele "feudo", uma vez que a sua sobrevivência advinha exclusivamente daquela terra de onde podia tirar o sustento de sua família. As mulheres também eram vítimas dessa situação, e por isso se calavam, aceitavam em silêncio a dor do abuso e sofriam duplamente, pois também acabavam sendo vítimas dos próprios maridos que se acovardam e descontavam toda sua frustração nelas, mutilando-as moral e fisicamente. Nesse sentido, a vida de Teresa Diaba, Brunilde, Emersinda, da mãe do narrador e da mulher queimada tinha algo em comum: eram mulheres excluídas daquela sociedade e estavam em condição inferior à da vaca, Sarga, já que "a vOz das mulheres, perigosa e burra, estava abaixo de mugido e atitude de nossa vaca, a sarga” (MÃE, 2010, p. 11).

Desse modo, pode-se dizer que, em O remorso de Baltazar Serapião, todas as personagens são, em alguma medida, zoomorfizadas. Contudo, o processo de desumanização se dá principalmente em relação às personagens femininas. Essas personagens são tidas como seres inferiores aos outros que habitam aquele espaço. Geralmente, elas estão associadas ao fogo e à simbologia da sedução associada a poderes malignos do diabo que levam o homem à perdição. A aliança com os animais aparece por toda a obra, indistintamente da personagem. Dom Afonso, por exemplo, se assemelha, conforme o narrador, a um gato, dada a sua esperteza e ardil: "sentei-me, ele redondo de inchado vermelho e rebentando, achegado a mim num golpe de corpo que o parecia bicho ágil, estranho gato, felino qualquer, estranho se o corpo dele não era para grandes proezas.”. (MÃE, 2010, p.62). Já Dona Catarina, esposa de Dom Afonso, apesar da influência e do poder que exercia sobre os empregados, também, por vezes, se porta como eles, dando-lhes patadas como uma égua ou uma vaca: “ai, dona catarina, não me obrigue, 
se lhe dissesse caía-me a língua só de medo. anda, rapariga, ainda te deito abaixo de patada bem dada.” (MÃE, 2010, p. 71). Nenhuma personagem está imune ao processo de aliança e de aproximação das atitudes humanas à dos animais, mas as mulheres, principalmente as camponesas, destituídas de poder e de valor, são tidas como de menor importância que o gado. Isso se ratifica pela preocupação e atenção dada a Sarga em detrimento das mulheres, como se pode observar: "era uma vaca como animal doméstico, mais do que isso, era a sarga, nosso nome, velha e magra, como uma avó antiga que tivéssemos para deixar morrer com o tempo que deus lhe desse.”. (MÃE, 2010, p. 29)

Além disso, a Sarga dormia dentro da casa como se fosse um membro da família, ao menos até o momento em que Baltazar se casasse e colocasse no seu lugar Emersinda, sua esposa, que ainda era para ele um amor platônico e, por isso, perfeito, assim como a Sarga:

era o que revia, à noite, nas palhas da cama achegadas de lado para lado na minha impaciência. o aldegundes a dormir de paz e eu no escuro a medir o arfar da sarga e a pensar como mudaria tudo. como aquele arfar sairia de dentro de casa e naquele mesmo lugar gemeríamos casados de fresco (MÃE, 2010, p. 34)

A Sarga era ainda uma espécie de amante dos homens daquela família, que mantinham relações às escondidas com a vaca, como relata o narrador:

pouco me importava a fama da família, já não era isso. só tínhamos de desviar as atenções do meu pai, não fosse ele saber das sevícias sobre a vaca, era bom que se agradasse de saber a masculinidade do filho posto na diaba, escola de tantos nós, mas da vaca eu não imaginaria que loucura lhe desse tal informação. (MÃE, 2010, p. 37)

Enfim, pode-se observar, nessa narrativa de Valter Hugo Mãe, ao menos um processo de inversão de valores relacionados à vaca e aos seres humanos, uma vez que a primeira é humanizada enquanto que os segundos são animalizados. É importante observar que as personagens femininas, além de serem zoomorfizadas como a maior parte das personagens, também passam por um processo de desumanização que as torna seres instintivos e por vezes até irracionais, cujas vozes são silenciadas e cujos corpos são mutilados. Nesse processo, as mulheres não são somente zoomorfizadas como as demais personagens, mas perdem mesmo as suas características humanas. Isso se evidencia em 
muitos momentos, como na seguinte passagem, em que Baltazar faz referência à Teresa Diaba:

\begin{abstract}
nas coisas do coração não entravam substituições, mas compensavam-se bem com devaneios do corpo a subalternizar o pensamento às aptidões daquele. por isso, busquei a diaba para me vingar nela do compasso a que estava tomado meu tempo (...) e a teresa apercebera-se da minha efusiva maneira e estrebuchava de prazer mais acelerada nos proveitos, como the apetecia sempre quando era brutalizada pelo homem que a atraía. a diferenca entre ela e uma vaca ou uma cabra era pouca, até gemia de estranha forma, como lancinante e animalesca sinalização vocal do que sentia, destituida de bumanidade, com trejeitos de bicho desconhecido ou improvável. e era como lhe vinha naquele fim de tarde, posta sob mim a bater com a cabeça no chão para se verter de submissão aos meus grilhões. (MÃE, 2010, p. 36, grifo nosso)
\end{abstract}

Essa passagem é bem emblemática e, de certa forma, sintetiza tudo o que foi analisado nesse artigo, ou seja, o fato de haver em O remorso de baltazar de serapião (2010) um processo de constituição das personagens a partir de um movimento duplo: zoomorfização e desumanização. Entretanto, considerando-se que a zoomorfização seria uma constante pertencente a quase todas as personagens do enredo, com exceção de El-rei e da rainha, já o processo de desumanização teria mais força e encontraria maior representação nas personagens femininas. As mulheres não só se assemelham aos animais em suas atitudes, mas são vistas como seres demoníacos, cujas vozes devem ser silenciadas, e por essa razão elas devem ser "destituídas de humanidade", valendo-se tão somente da "submissão" a seus senhores. Enfim, o acorrentamento dessas personagens se dá em um espaço feudal e, para não evitar a rima, infernal, onde as relações são construídas a partir de um padrão de poder que faz com que alguns detenham o poder em relação a outros e, com isso, sejam capazes de lhes botar cabresto para que se tornem mansos e percam a sua capacidade de lutar por sua individualidade e autonomia.

O romance de Mãe está sob o signo do fogo da sedução, do poder e da morte, que faz com que os homens se destruam mutuamente, principalmente os mais remediados. Após o feitiço de uma bruxa, a mulher queimada, Baltazar, Aldegundes, seu irmão, e Dagoberto, amigo que fizeram no caminho da visita a El-rei, são amaldiçoados, uma vez que não poderão mais andar separados uns dos outros a não ser que encontrem outra feiticeira que possa lhes retirar o bruxedo, o que não ocorrerá até o fim da história. Ao voltarem para o vilarejo, acabam sendo expulsos, pois em tudo que tocavam causavam 
dano de morte, fervendo na brasa que os três eram capazes de desferir e chegavam com isso a seguinte conclusão: "somos pertença do diabo, espumaremos se entrarmos em espaço sagrado, e parámos a chorar.” (MÃE, 2010, p. 141). O demônio, de fato, parece rondar o destino de Balatazar e dos seus, se for considerado que o enredo tem como exegese a Idade Média. Essa certamente é a única explicação possível para aqueles desafortunados personagens, explorados pelo senhor feudal Dom Afonso. Na perspectiva medievalista, a culpa só podia ser do diabo e/ou da ausência de Deus. Dessa forma, nesse contexto, alguns homens podem ter sido eleitos por Deus, como é o caso de El-rei e de Dom Afonso, e por isso podiam decidir sobre o destino dos outros homens, que eram "bestas", filhos do diabo, "cornos", como Baltazar faz referência a todo instante. Isso ocorre também quando Dona Catarina se refere a Emersinda em um diálogo com Baltazar: "a tua mulher é osso de corno que te salta à cabeça, e que te põe o nome nas vergonhas de tantos homens quantos imagines existirem aqui na terra.” (MÃE, 2010, p. 172).

Conforme Jean Chevalier:

O Diabo simboliza todas as forças que perturbam, inspiram cuidados, enfraquecem a consciência e fazem-na voltar-se para o indeterminado e para o ambivalente. (...) Todo o papel do diabo é esse: espoliar o homem, tirar-lhe a graça de Deus, para então submetê-lo à sua própria dominação. (...) Ele é a síntese das forças desintegradoras da personalidade. (CHEVALIER, 2007, p. 337, grifo do autor):

Sob essa perspectiva, as personagens do romance de Mãe vão, em seu percurso, ao encontro do diabo. Afinal, elas são incapazes de ter consciência de suas próprias vidas e vão em direção ao "indeterminado". Parece que estão num mundo sem eira e nem beira, comportam-se como animais, tanto no que isso tem de positivo quanto no que há de negativo. Vão se desintegrando ao longo do romance, principalmente as mulheres, que vão sendo mutiladas paulatinamente por seus machos. Nessa caminhada, só sobrevivem os fortes, os escolhidos de Deus: Dom Afonso, Dona Catarina, El-rei e a rainha. A família vai se desintegrando: a mãe doente morre; Brunilde é morta em aborto malsucedido à espera possivelmente de um filho de Dom Afonso. Afonso, pai de Baltazar, fica sozinho, velho e sem forças, após expulsar os filhos. Os personagens, pobres camponeses, vão em direção ao matadouro, como gado, um após o outro, até o desfecho dramático da trama. Nesse momento já estão longe, envoltos na escuridão da noite, Baltazar, Aldegundes, Dagoberto, 
Emersinda e claro, a Sarga, rumo ao seu destino final, ao encontro inevitável com a morte, já que não lhes vão poupar a vida:

aproximei-me dos dois, grande e imbatível como uma pedra de ódio construída no exercício do meu bom amor, e me pus diante deles tão pequenos. afastaram-se da minha emersinda que, imóvel, respirou menos, respirou menos, respirou menos, não respirou. A sarga mugiu de modo lancinante, e eu abati-me sobre os dois abrindo lado a lado os braços de punhos fechados. um só golpe com a violência da pedra mais furiosa do mundo. sobraram no chão como nada ali estivesse. depois ergui-me, aqueci, tive a percepção fatal de que o meu corpo não suportaria nem o caminho até ao pé da sarga, na escuridão contínua, a sarga talvez tentasse chegar a mim também. (MÃE, 2010, p. 194)

\section{REFERÊNCIAS BIBLIOGRÁFICAS}

CHEVALIER, Jean. Dicionário de símbolos. Tradução Vera da Costa e Silva (et al.). 21 ed. Rio de Janeiro: José Olympio, 2007.

DELEUZE, Gilles. Mil platôs: capitalismo e esquizofrenia, vol. 2. Tradução de Ana Lúcia de Oliveira e Lúcia Cláudia Leão. São Paulo: Editora 34, 1995.

Mil platôs: capitalismo e esquizofrenia, vol. 4. Tradução de Suely Rolnik. São Paulo: Editora 34, 1997.

MÃE, Valter Hugo. o remorso de baltazar serapião. $1^{a}$ ed. São Paulo: Editora 34, 2010. 